\title{
Intergenerational integration, social capital and health: a theoretical framework and results from a qualitative study
}

\author{
Integração intergeracional, capital social e saúde: \\ arcabouço teórico e resultados de um estudo qualitativo
}

${ }^{1}$ Departamento de Saúde Coletiva, Faculdade de Ciências da Saúde, Universidade de Brasília. Campus Universitário Darcy Ribeiro $\mathrm{s} / \mathrm{n}^{\circ}$. 70910-900 Brasília DF. elzadesouza@terra.com.

\begin{abstract}
The purpose of this paper is to report results from a qualitative evaluation of a school based intergenerational intervention and also to derive a theoretical framework to explain the changes of attitudes in an intervention of this kind. This is a qualitative evaluation of an intervention where 32 elders from the neighbouring area of a secondary school of Ceilândia, Distrito Federal (DF) of Brazil shared their memories with the 111 students during four months. After the intervention, adolescents and elders took part in 14 focus group discussions where they evaluated the effect of the activities in some aspect of their lives. The intervention had a positive impact in the participants' perceptions of family relationships, health status and solidarity. However, it did not improve feelings of trust in others. The results also suggested other possible dimensions of social capital for these age groups such as mutual respected and perception of being valued by others. Although the study had some limitations, it showed the possible mechanisms of psychosocial changes involved in interventions of this kind which have not been investigated.
\end{abstract}

Key words Health, Social capital, Intergenerational interactions, Theoretical framework, Reminiscence processes
Resumo O propósito deste artigo é apresentar os resultados de um estudo qualitativo para avaliar atividades intergeracionais desenvolvidas em uma escola de ensino fundamental e descrever o arcabouço teórico utilizado para explicar as mudanças envolvidas nesse tipo de atividade. Foi feita avaliação qualitativa de uma intervenção em que 32 idosos da área de abrangência de uma escola de ensino fundamental de Ceilândia, Distrito Federal, Brasil, compartilharam suas memórias com 111 alunos durante quatro meses. Depois da intervenção, idosos e adolescentes participaram de 14 grupos focais em que discutiram o efeito das atividades em alguns aspectos de suas vidas. A intervenção teve um impacto positivo na percepção dos participantes referente à relação familiar, autopercepção do estado de saúde e solidariedade. No entanto, não afetou os sentimentos de confiança mútua. Os resultados também sugerem possíveis dimensões de capital social para esses grupos etários, tais como respeito mútuo e sentimento de serem valorizados, ainda não investigados. Embora com limitações, este estudo mostrou os possivveis mecanismos de mudanças psicossociais que ocorrem nesse tipo de intervenção.

Palavras-chave Saúde, Capital social, Integração entre gerações, Arcabouço teórico, Reminiscências 


\section{Introduction}

Social capital refers to dimensions of social relationships which might facilitate cooperation for the achievement of common goals ${ }^{1}$. According to a series of authors, social capital is associated with better government performance, the functioning of democracy the prevention of delinquency ${ }^{2,3}$ and also to improve health status ${ }^{4-7}$. However, there is very little qualitative information from intervention studies intended to build social capital, particularly to empower specific groups such as adolescents or older people.

Intergenerational programmes refer to activities where different generations interact to achieve some objectives ${ }^{8}$. Studies suggested that such activities might increase cognitive components of social capital such norms of reciprocity and solidarity, family relationships and self rated health status ${ }^{9,10}$. However, there is still a need for the development of a theoretical framework to explain how and why such changes occur in intervention of this kind ${ }^{11,12}$.

The purpose of this paper is to report results from a focus group study designed to evaluate a school based intergenerational project and to derive a theoretical framework to explain the process of changes in attitudes involved in such activities.

\section{Conceptual framework}

A number of initiatives have attempted to use the community approach to change behaviour, based on the principle of participation ${ }^{13}$. Because change is the main goal of most community intervention studies, it is important to understand how and why such changes occur.

The general principle of social change includes theories at individual and community level. For the purpose of this study only three individual level theories were considered as they were the basis of the framework developed in this investigation and will be briefly mentioned as they were well described elsewhere ${ }^{11}$.

One of the best known intrapersonal-level theory is the Theory of Reasoned Action (TRA) $)^{14,15}$, which assumes that the predictor of behavioural change is the "intention" to change certain behaviour. That intention is shaped by "attitudes" towards that behaviour. On the other hand a well known interpersonal-level theory in the health field is the Social Learning Theory $(\mathrm{SLT})^{16}$. According to the this theory the individual acts on and reacts to environmental stimuli and acquires new ideas and behaviours by modelling them on focal others. Another social theory developed by Freire $(1973 / 1994)^{17}$, is based on critical dialogue, which leads to a joint understanding of reality and consequently promotes individual and social changes ${ }^{18}$.

Based on a combination of the mentioned theories the Social Learning, Dialogical and Reflective Theory (SDRT) was developed by the author $^{11}$ as a framework to support the principles of the present research. This pivots around the argument that guided activities that promote social contact (exposure) between elderly and young people could influence both age groups by favouring environmental changes and providing consistency of information through dialogue, which may lead to reflection by comparing shared experiences (reasoning, critical views and better understanding of reality) and, by doing so, modelling themselves and creating new ideas which change previous beliefs. This change of beliefs will shape new attitudes which can result in an improvement of the wellbeing at individual and community levels. Based on this argument, the study was guided by the assumption that intergenerational interaction facilitated by reminiscence processes may have a positive influence on participants' perception of family relationships, health status, trust in others, solidarity and reciprocity (Figure 1 ).

\section{Method}

This article is the third derived from a triangulation designed to evaluate a school based intergenerational project based on the assumption that intergenerational interaction through reminiscence processes may influence various aspects of life of elders and adolescents involved in this type of activities. The first article of the series described the multi-methodology involving a community controlled trial, focus group technique and process evaluation ${ }^{11}$, the second reported the results from the community controlled trial ${ }^{9}$. In this paper only the focus group study will be described. Reminiscence processes which means recalling the past was chosen as a means of interaction considering its importance for the individual and for the community ${ }^{19,20}$.

\section{Study setting}

The study was undertaken in Ceilândia, Distrito Federal (DF) of Brazil, which was chosen 
Figure 1. Schematic representation of blended theory (SDRT) to explain the influence of the intergenerational interaction intervention on the participants of the study.

because the city comprises a low urban income area established in the 1960s with the founding of Brasília. And also because more than fifty per cent of its population, aged 42 and over in 2002, came from elsewhere ${ }^{21}$. Thus Ceilândia, has a range of characteristics, like a number of similar areas, which may predispose to poor levels of social interaction, which suggests a need to develop interventions to promote social cohesion.

\section{The programme implementation}

The intergenerational programme was implemented from July to November 2002 in one secondary school of Ceilândia, $\mathrm{DF}^{11}$. For this study, the target population was formed by two age groups: one sample was composed of 32 ran- domly selected elders of sixty years old and over, living in the catchment area of the selected school (Centro Educacional 7). Students from five classes of the $7^{\text {th }}$ and $8^{\text {th }}$ grades of the chosen school, ranging in age from 12 to 18 years old randomly selected comprised the other sample. The exclusion criteria included elders and adolescents already participating in any reminiscence programme, severe alcoholism, severe speech and memory impairment, and bedridden due to serious illness.

The students and elders had the chance to share their life stories in sessions of approximately two hours each week, in a mean of 14 sessions. The classes of, on average, 23 students were divided into smaller groups during sessions. The activities took place in groups generally including ap- 
proximately 10 adolescents and 2 elders. In the sessions memory triggers such as interviews, photographs and old objects were used. During the sessions the groups discussed different subjects and took part in a range of activities as shown in Box 1. By the end of the project they prepared an exhibition with the products from the sessions.

\section{Data collection}

After 4 months intervention, data was collected from both elders and adolescents through fourteen focus groups. Ten groups of on average nine participants were conducted with adolescents, and four, on average comprising six people, with elders as detailed in Figure 2. The groups were run using a focus group guide well described in a previous paper ${ }^{11}$. The group discussions took place at the school. Each one was attended by a facilitator and an observer, who was also responsible for the tape transcriptions.

Ethical approval from the Ethical Committee of State Secretariat for Health of Brasilia, DF, Brazil was obtained. Written consent was required from all participants and also from the adolescents' parents.

Box 1. The activities developed during the reminiscence sessions.

\begin{tabular}{|c|c|c|}
\hline Topics discussed & Workshops & Joint celebrations \\
\hline $\begin{array}{l}\text { - Plays, toys, school days } \\
\text { - Special parties } \\
\text { - Solidarity now and then } \\
\text { - Courting and marriage } \\
\text { - Wedding parties } \\
\text { - Migration } \\
\text { - The history of Brasilia }\end{array}$ & $\begin{array}{l}\text { - Fabric dolls } \\
\text { - Paper and sock balls } \\
\text { - Looking good in old dresses } \\
\text { - Cartoons and books } \\
\text { - Typical food }\end{array}$ & $\begin{array}{l}\text { - The Adolescents' and Elders' National } \\
\text { Day (Picnic to a botanical garden) } \\
\text { - Birthdays of some of elder and young } \\
\text { participants } \\
\text { - Exhibition of the products of the } \\
\text { workshops }\end{array}$ \\
\hline
\end{tabular}

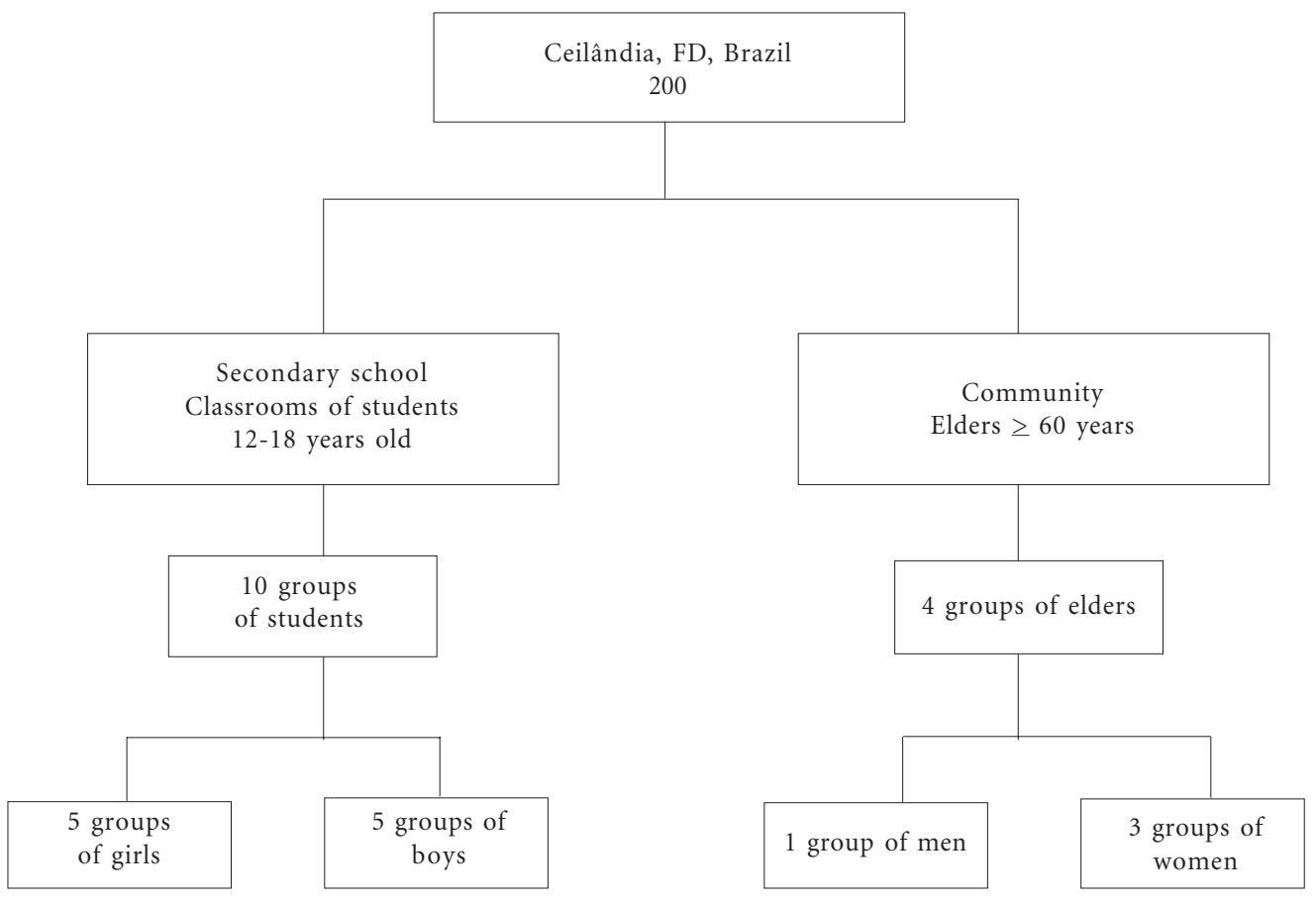

Figure 2. Focus groups sampling design. 
Box 2. Summary of major codes and sub-codes created to analyse focus groups data using $\mathrm{N}^{\star}$ UDIST 5 Package and manual coding.

\begin{tabular}{|c|c|}
\hline Major codes & Sub-codes and tree codes \\
\hline \multirow{3}{*}{$\begin{array}{l}\text { Impression } \\
\text { of the project (both } \\
\text { elders and adolescents) }\end{array}$} & $\begin{array}{l}\text { Positive points: } \\
\text {. Learning from the past } \\
\text {. Mutual learning } \\
\text {. Mutual respect } \\
\text {. Self-worth } \\
\text {. Love }\end{array}$ \\
\hline & $\begin{array}{l}\text { Negative points: } \\
\text {. Time (short duration) } \\
\text {. Low number of elders } \\
\text {. Poor organization at the beginning }\end{array}$ \\
\hline & $\begin{array}{l}\text { New findings: } \\
\text {. Importance of being valued } \\
\text {. Importance of being respected } \\
\text {. Perception of being discriminated }\end{array}$ \\
\hline $\begin{array}{l}\text { Family relationships } \\
\text { (adolescents) }\end{array}$ & $\begin{array}{l}\text { Improvement with parents } \\
\text {. Improvement with grandparents } \\
\text {. Improvement with brothers and sisters }\end{array}$ \\
\hline $\begin{array}{l}\text { Family relationships } \\
\text { (elders) }\end{array}$ & $\begin{array}{l}\text { Improvement with grandchildren } \\
\text {. Improvement with children } \\
\text {. No improvement } \\
\text {. Improvement }\end{array}$ \\
\hline Health status & $\begin{array}{l}\text { Psychological improvement } \\
\text {. Physical improvement } \\
\text {. Social improvement } \\
\text {. No improvement }\end{array}$ \\
\hline $\begin{array}{l}\text { Cognitive components } \\
\text { of social capital }\end{array}$ & $\begin{array}{l}\text { Feelings of been respected } \\
\text { Feelings of self-worth } \\
\text {. Feelings of been valued } \\
\text { Trust people in general, family, friends and neighbours } \\
\text {. Reciprocity and solidarity }\end{array}$ \\
\hline $\begin{array}{l}\text { Recommending the } \\
\text { project (adolescents) }\end{array}$ & $\begin{array}{l}\text { Schools, institutions for recuperation to prevent violence, } \\
\text { Orphanages } \\
\text {. Elders in general, young people in general } \\
\text {. Drug users, parents, mentally ill people, disabled people }\end{array}$ \\
\hline $\begin{array}{l}\text { Recommending the } \\
\text { project for (elders) }\end{array}$ & $\begin{array}{l}\text { Schools in general } \\
\text {. Young drug users } \\
\text {. Elders in general }\end{array}$ \\
\hline
\end{tabular}


where the quotation appeared in the transcribed text.

\section{The general opinion of participants}

The focus groups discussion started with the general opinion of participants about the activities.

The boys and girls reported that the project gave them the opportunity of self expression, and mutual learning (We learned a lot. The project influenced our way of thinking and our behaviour. We expressed our emotions. G1:363-36). However, learning about the past and learning how to respect elderly people were the most relevant factors (We learned how to respect elderly people because they are our relics of the past. G2:1112). They started respecting elders and also wanted others to do so (I learned how to respect elderly people and I wish others could respect them too. G7:525-526). They also stressed the kind way elderly people treated them.

The elder men pointed out enjoying the project because it bridged the gap between generations and gave them the chance to see a positive side of young people (I liked it because I met these young people, some were very attentive with us, other a bit more rebellious but I met them and I liked it. G14:45-46). The project also gave them the opportunity of self expression and brought them the opportunity of making new friends (In our group, nobody knew each other before and now we are all friends. It was important because we improved each others' knowledge. G14:12-13). The statements seem to corroborate the idea of learning by social contact and the dialogue as a consistent source of information and knowledge, which facilitated change in the elders' preconceptions about younger generations. However, the most important point raised was the perception of being valued (It was very good because it entertained us and we got recognition from people. (G12:6-7). The men realised that they were appreciated by others as reflected in the following comment: We could not pave this pathway on our own, you gave the guidance, the school opened its doors, the students welcomed us and we achieved more respect (G14:273-278).

For the women, positive aspects included feeling respected, a sense of freedom achieved, and strengthening friendships. But, like the men's opinion, the most important aspect was the perception of being valued (We felt useful, at ease, bigger and better. For this reason I enjoyed coming here because we were valued. G12:473-476; Everything, the attention we received here, we knew another reality because nobody even our family, nobody cares about us, but here I felt as though I were someone. G12:123-127).

The participants anticipated the benefits of the activities for other groups. Both boys and girls would like to recommend them to the young and to elders and to their parents. The reasons for recommending it to the elders were for them to feel useful (There are elderly people who feel useless, so they could come here to learn they are not. G8:329-331). This comment could reflect the interest in bringing the elders into the activity, but it also reflects the fact that they themselves had the feelings that elders were useless as it was mentioned by all groups.

The reasons for recommending the project to young people varied. As a particular reason, they suggested the activities would prevent delinquency and drug abuse among adolescents (It could be used to prevent violence among young people because most elderly people did not need to be thieves or murderers or even drug users or diallers to survive. G6:398-400). According to their explanation, by listening to the elders' histories, the young offenders could make a parallel between their own lives and the elders' and reflect that the elders live in the same environment, on very low monthly wages and did not became involved in delinquency in their youth. By comparison, they think the young people could reflect and reason on good examples and even change their behaviour.

The adolescents are aware of the violent location they live in, but they know it is possible to improve life even in places like Ceilândia. (If I were in charge to start a project like this I would start it for the drug addicted. G2: 227-228). According to their point of view, the intergenerational activities could help to form a chain of improvement (You see how the project helped us? Before, we were not aware of the world. We are used to crime in Ceilândia but we know what is right and what is wrong. So, we can develop good ideas to improve peoples' lives. One good idea triggers another one, then it grows till it forms a big chain and a better society. G6:409-415).

Through the project the students seem to understand the importance of cohesion for mutual benefit. They also had an idea that if the community were cohesive it would have more strength (Really if the community were cohesive it would be stronger and give us political strength; the elders would not be abused, it would be better. G4:258-260).

Both boys and girls alike would recommend the project to their parents. They mentioned that 
if their parents took part in the activities they would be more understanding and respectful towards their children. They also think their parents would become less shy to discuss sensitive subjects like sexual matters and learn how to express themselves (If our parents could take part in the project, I think many children would stop making love as early as 12 or 13 years old, the children would understand their parents and both sides would understand each other. G8:365-367).

Two groups of girls recommend it to the orphanages. They thought the elders could alleviate orphan's feelings of abandonment and also to establish family like ties. This feeling of establishing family like ties was felt by their own experience (Like Mrs. M said she feels as we were her grandchildren, so the orphans could feel as the elders' were their grandparents. G7:308-310).

Like the students the elders also suggested that the activities might prevent drug use and violence. They realised the young people need love and understanding (I would like to recommend it to the adolescents because they are in need of love and understanding. Sometimes they do not get it even within the family. G13:224-227). They also suggested them for the adolescents' parents as a means of learning how to provide more support for their children (The family would take part because here they would learn how to love their children... Yesterday one young guy who lives in my street was arrested by the police and the police abused him physically. I was sorry for him because his parents brought him up in a drug dealing environment. G13:244-2).

These comments suggest that participation in the project led to more empathy with young people and some understanding that young people may get into trouble because their family relationships are problematic.

\section{Negative aspects of the project}

Although the adolescents had pointed out some benefits, they identified many negative points, which jeopardised the activities, including changes and interruption of topics without fully completing them, and changing previously planned topics for discussion at the last minute (I did not like it when we were debating, eager to continue the discussion and we had to shift the topic without finishing the previous one. G4:234-237). The most negative aspect, however, was related to the duration of the project (It became very good when the elders started telling their life stories. But, when we felt like telling them the meaning of our lives and how we have overcome our own difficulties the project finished. G4:264-266). They considered the elders' lives difficult and were impressed by the way they overcame the difficulties. When they felt more confident, had overcome shyness, and were able to confide in the elders to share their histories in a deeper way the project was over. They suggested that something was missing and they could not fully enjoy the activities.

One group complained about the way some group facilitators (teachers) conducted the groups, restraining their dialogue with elders, which impaired their spontaneity. They mentioned that one monitor was very critical, always putting the students down and giving them very little support not only in the reminiscence project but during normal classes (Teacher $B$ is very hard she did not allow us to have a spontaneous conversation with the elders. Always criticising us saying we were very noisy. She is very hard during her classes too. G5:111-113).

It is possible that, as the students usually do not have the opportunity to express themselves, they took this opportunity to raise some criticism about teachers instead of being supportive, over used their power to restrain the students.

As a result of organizational problems they had to work without a group facilitator for most of the time. This gave them the opportunity to show their worth (With the teacher around us everything had to be planned but when we were on our own it was spontaneous, it flowed beautifully and we felt like keeping going. We showed we were able to co-operate in many ways. It was very good! G10:229-231). Although this statement showed self-confidence and pride, it can also be interpreted as a way to draw attention to the fact that they have been taken for granted.

The negative aspects mentioned by all groups of elder participants included the low number of elders. They also complained about the short duration of the programme (I enjoyed it very much but the time was very short. G11:7).

\section{Impact on family relationships}

Boys and girls reported that the project brought them a better understanding of parents and grandparents (...the elders told us how their family treated them when they were children. They had no freedom to play in the streets they had hard tasks within the family and were strictly punished... Then I started valuing my life and I said to myself: I must be more considerate with my family. G4:302-307). The reflection and change expressed 
in this statement was shared by all groups. It suggested that the dialogue with elders, brought them reflection on the way they perceived their parents. In doing so, they realised they could be more understanding and sympathetic and less demanding (Before the project if my mother said she could not afford things I asked for I used to be very upset with her. Now I can see that not everything in life is the way we want. G3:367-371). It also seems that made them reflect on the intention to change and value their parents more. It seems that the dialogue with elders also brought consistency of information that adolescents needed to believe in their parents and accept their opinions (My father always said I have a good life compared with his hard childhood. I did not listen to him, but here listening to the elders' histories I realised he was not lying because all the elders told us the same stories. So I realised he was right. G2:287-290).

The students started changing the way they treated their grandparents. Apparently, the changes occurred through the same mechanism of establishing parallel and comparing youth in the past and today (Now I value my grandfather. I consider his opinions and choices. I became more patient and more sympathetic with him. G6:268269). It is possible that some of the students took their grandparents for granted. For many students they started taking the initiative to talk to their grandparents and the relationship improved (For me it also changed because I did not care for talking to my grandfather, now I am taking the initiative to talk to him and our relationship has become much better. G1:430-430).

They also started reflecting on how they take their lives, their family and even material things for granted. They started considering how fortunate they were for having, schools and amenities which were rare in the past (We did not value our school that is close to our place. In the past they [the elders] had to walk on foot miles away to go to school, it was very difficult but they did. We do not value what we have at home, now we are learning. G:63-66).

If, on the one hand the adolescents mentioned they could be more understanding, on the other hand they revealed their resentment towards their family and society in general. They accused their parents of exerting their power without allowing them to express their feelings and opinions (They [parents] are not able to see our side, only their views are right. They ignore our opinion. Even in cases when we are right, their words have to prevail, they do not hear us. G10:485-492; If I get upset because I know I am right everybody at home gangs up against me and says: Even if you are right shut up and listen to your mother. G10:505-507). They also showed their perceptions adults in general had a stereotyped image of them, labelling them as rebellious, lazy, irresponsible and prone to violence, without given them the opportunity to defend themselves (Unfortunately society considers us all the same way. We are seen as if we were all the same without exceptions. G1:350-351). In Brazil it has become common, to refer to adolescents as "aborrecentes" (annoying). What may only be a matter of an adult jokes and play on words, reinforces the stereotypes against this age group, and hurts them deeply (We are labelled "aborrecentes", they think we are annoying beings who do not reason before talking and so talk nonsense. G10:121-122).

Among the older men, only one mentioned change in the way his family started recognising his value after being in the project, as he mentioned: At home they used to call me useless old man and things like that. Now they noticed I have been valued (G14:531-533). No other participant mentioned any change.

The women mentioned being more encouraged, being better treated and more valued by their children. Some also mentioned becoming more understanding with their children and grandchildren by observing young people outside the family environment. Through the dialogue they realised that young people have needs, have problems with family but also that they are able to be caring and respectful. It gave them the opportunity to reflect on their own situation at home, became more sympathetic with their own young people and the relationships improved (Before coming here I had frequent arguments with my daughter and was very demanding with my granddaughter. G13:187-190; I changed because here we learned how to be more humble and more understanding with our family. G13:380-381).

The above statements suggest that the women changed their attitude towards their children and grandchildren. Socially-constructed stereotypes can be aggravated by tense relationships. This vicious circle reinforces the negative attitudes between generations if they do not have the opportunity to experience good relationships outside the families.

\section{Health status}

The adolescents seemed to have a clear understanding that being healthy is a state of psy- 
chological, physical and social wellbeing. They mentioned several times that being cheerful, feeling less shy, less stressed and being in good terms with their family was a sign of health for them and for the elderly people as well (The project brought many benefits. When we were sad, we became cheerful and calmer. It improved our mental condition and the elders' as well. G5:97-102). It was stated that the dialogue with the elders gave them more knowledge about themselves. By having some terms of comparison they reflected on their own lives and by reasoning about their lives and the elders' they got a better understanding of reality. It brought them more psychological strength as they felt a sense of self worth. It also brought them some insights to recognise that they had been taking their lives for granted (I think the project gave me an opportunity to improve my understanding of myself and improved my self-esteem. G1:252-253). They perceived their wellbeing but also the elders'. Some adolescents mentioned feeling stressed, for different reasons such as school pressure, family and financial problems. This was stated many times in different groups (I think that we became emotionally stronger, able to use our time at school in a more productive way and also the project made us calmer to be able to understand mathematics as it is a discipline which makes us very stressed. The project made us going back home feeling calmer and more cheerful because the elders made us more cheerful. G9:239-244). According to their perception, taking part in the activities kept them busy and also improved their state of mind because they made comparisons with the elders' attitudes (It helped me because I am very stressed and impatient and so I started observing the elders. It brought me some reflection because they have lived many years and did not seem stressed and I, who had not lived half of my life was feeling like that, so I reflected on my own situation. G4:228-231).

For the elder men, it seems that there was no improvement in perceived health status. Although they had mentioned improvement in socialisation and the opportunity to make new friends, they did not perceive those aspects as an improvement in health (It influenced how we felt because we got rid of the monotony of home. It was a chance for us to have contact with other people. Even though we did not feel it improved our health, we felt better anyway. G14:299-404). The women mentioned improvement in their health status ( $I$ improved quite a lot. I used to go very often to the emergency care, but since I started here I never went back to the hospital. G11:211-213). It also brought psychological improvement (Being at home on our own brings us depression. Loneliness ruins us. G13:428-429).

The group discussions seem to suggest that the changes mentioned above occurred through social contact which gave the participants the opportunity to establish an open dialogue. This contact and dialogue were the bases for reflection and comparison between their previous and present attitudes related to the dimensions discussed here.

\section{Components of social capital: trust and reciprocity}

It seems that trusting people outside the family environment is a difficult task. Participation in the project brought very little change either for adolescents or elders. Some adolescents had quite fixed views on this subject (I only trust God. It is not possible to trust anybody else. G1:535-536). According to them even those considered as friends are not reliable in some respects. When the subject involves money they think it is even worse (In an issue involving money, people want to take advantage. Most people are ambitious and take advantage if they have a chance. G7:174-177). For the elders although they mentioned making new friends and strengthening friendship, they stated that it takes a long time to trust others.

Although no changes were seen in trust, it seems that the norms of reciprocity were strengthened, as mentioned in all groups of adolescents. They became more sympathetic with others, particularly with parents, grandparents and elderly people (The project became associated with friendship, love, patience and compassion for people. G1:695-697). The word "love" came out in the discussion several times in different groups when different subjects were discussed. Reciprocity also came in the form of mutual respect and understanding (We were afraid of them [the elders] and they were afraid of us, but they realised we were not the way they thought and started to be more open and we also changed our impression about them. G2:447-449).

The women mentioned they had opportunities to share their feelings with others in the groups (My nephew was severely ill nearly dying. Here I could share this situation. It was a relief for me. G13:160-161). But when asked if they felt helped by others they gave a negative answer (No, unfortunately, the fact of being here did not help us to get external aid. G12:728-729). It seems that they understand help in the sense of material things, 
as one woman stated her disappointment because she did not succeed in getting her state pension as she thought she could through the project.

\section{Discussion}

The findings from the present study suggested for the adolescents a positive relationship of the intervention on self rated health status, attitudes towards elders, family relationships, sense of solidarity and reciprocity, which support the results from the quantitative results based on a community controlled trial study mentioned before and described elsewhere ${ }^{9}$, which suggested a positive relationship of the intervention on self rated health status and attitudes towards elderly people.

The positive association between the intervention and attitudes of adolescents towards elders was supported by all groups of boys and girls, mentioning improvements in their impression of elderly people. Similar positive changes were reported in previous studies in Sweden ${ }^{24}$, in Brazil ${ }^{10}$ and in the USA ${ }^{25}$.

These findings can be interpreted in the light of Bandura's Social Learning Theory (1969) ${ }^{16}$ and Freire's Dialogical Theory (1973-1994) ${ }^{17}$ as changes seem to have occurred through social contact during life stories sharing. The dialogues provided consistent information which in turn led to reflection and change in attitudes. These reflections and changes may suggest the Reasoning Action $^{14}$. This sequence of events seems to support the changes in attitude towards elderly people and old age proposed in the framework which guided this study (Figure 1). It also accords with Chellam $^{25}$ and Britt ${ }^{24}$ who refer that in the process of interaction, youth and the ageing socialise with each other. There are exchange of values and functional interchange. The cross-generational perceptions of each other, however, depend on the quality of intergenerational contact.

The findings suggested that the activities improved their sense of self-worth, and capability to express their disappointment in realising how adults and society in general discriminate against them and their resentment that they are labelled without exception in a negative way. This finding accords with the work done by Morrow ${ }^{26}$ in the UK. If stereotypes influence health and the performance of elderly people as stated in the studies of Hausdorff and colleagues ${ }^{27}$, it is possible that the performance and self image of adolescents be influenced by stereotypes and attitudes towards young people as well. However, this influence was not investigated in the present study. This should be investigated in future research.

The adolescents perceived health as a state of general wellbeing. The participation made them to forget some stressful events in their lives, improving their mood and calming them down. It seems that improving the social environment was a key factor for their wellbeing as suggested in other studies ${ }^{6,7}$.

The analysis suggested that through the mutual contact the adolescents could see more clearly their reality. They realised how privileged they were in comparison with youth of the past. However they mentioned poor communication with parents, which, according to them is one factor responsible for the inappropriate behaviour of adolescents.

The results of focus groups discussion for the elders suggested an improvement on health status, family relationships and attitudes towards adolescents and better relationship with neighbours. A quantitative study mentioned previously ${ }^{9}$ supports the findings related to family relationships improvement and the perception that neighbours help each other, one of variables considered as norms of reciprocity.

Studies of attitudes have usually focussed on attitudes towards elderly but the adults' attitudes towards young people have rarely been investigated. This one sided view makes comparison with other studies difficult and also suggests a biased and possibly patronising view that only elderly people are influenced by stereotypes. If on one hand it is argued that stereotypes, positive or negative, can influence care and policies towards elderly people, then it would also seem plausible that how older adults regard young ones might influence policies and the participation of young people in the community. A more balanced approach to issues of ageism and stigma, and comprehensive policies to counteract them might benefit the community as a whole.

It seems that the guided contact of elders with young people outside the family environment brought them a better understanding of their reality and influenced their perceptions towards their children and grandchildren and towards themselves. As for the young people, as for the elders it seems that changes followed the pathways of social theoretical framework described in Figure 1.

In relation of trusting others, both, qualitative results described here and quantitative results described elsewhere ${ }^{9}$ for both age groups failed to show any improvement. One reason for 
not improving trust is probably because the time of the project was short, as mentioned many times by all groups. Another possibility is that cognitive components of social capital in these age groups and in poor areas have cognitive dimensions other than trust and reciprocity such as feelings of being valued by others, feelings of self worth and the perception of mutual respect. These dimensions need to be explored in further research.

This study presents a few limitations. One is related to possible researcher bias as the first author was the coordinator and evaluator of the project. In order to minimize these effects and increase reliability, the research procedure was carefully documented, as suggested by Silver$\operatorname{man}^{28}$. The interviews were audio taped, the opinion of an external observer were asked and also one focus group was translated and discussed in a workshop with research students and one expert qualitative lecturer at London School of Hygiene and Tropical Medicine for coding and interpretation. Another limitation is related to the duration of the project. It is possible that if the intervention had lasted longer it would show a better result.

\section{Conclusion}

This research was the first to evaluate an intervention intended to build social capital and to develop a theoretical framework to explain psychosocial changes that might have occurred by using reminiscence processes as a source of information for the participants. However, a further important message was that qualitative approaches are essential in order to identify underlying processes and detect more subtle changes.

It showed findings which were not the objective of this research such as the influence of intergenerational activities to prevent violence and drug use among young people. The study also had value in showing some possible dimensions of social capital for young and elderly people which are still under investigated. It also shed light on topics which deserve more attention in further research and also that these age groups need to be given more opportunities as both, elders and adolescents are important source of human capital which has not been fully explored to contribute to building a more cohesive and healthier society.

\section{Acknowledgements}

This research was part of a $\mathrm{PhD}$ thesis undertaken at the Department of Epidemiology and Population Health; London School of Hygiene and Tropical Medicine, which was supported by Capes (Coordenação de Aperfeiçoamento de Pessoal de Nível Superior, Brazil). Additional funding for fieldwork was provided by the UK Department for International Development. 


\section{References}

1. Islam MK, Merlo J, Kawachi I, Lindström M, Gerdtham UG. Social capital and health: does egalitarianism matter? A literature review. Int J Equity Health 2006; 5:3. [cited June 2008]. Available: www. pubmedcentral.nih.gov

2. Coleman JS. Foundations of social theory. Cambridge, MA: Harvard University Press; 1990.

3. Putman RD. Making democracy work. Princeton: Princeton University Press; 1993.

4. Kawachi I, Kennedy BP, Glass R. Social capital, and self-related health: a contextual analysis. American Journal of Epidemiology 1999; 89(8):1187-1193.

5. Harphan T. Measuring the social capital of children. Working paper n. 4. Young lives: an international study of childhood poverty. 2003. p. 1-14 [acessado 2009 fev 15]. Disponível em: http://www. socialcapitalgateway.org/NV-eng-measurement.htm

6. Fitzpatric KM, Piko BF, Wrigh DR, LaGory M. Depressive symptomatology, exposure to violence, and the role of social capital among African American adolescents. American Journal of Orthopsychiatry 2005; 75(2):262-274.

7. Kim DS. Experience of parent-related negative life events, mental health, and delinquent behaviour among Corean adolescents. [abstract] Journal of Preventive Medicine and Public Health 2007; 40(3): 218-226.

8. Brownell P, Resnick RP. Intergenerational-multigenerational: are they synonymous? Journal of Intergenerational Relationships 2004; 3(1):67-75.

9. Souza EM, Grundy E. Intergenerational interaction, social capital and health: results from a randomized controlled trial in Brazil. Social Science and Medicine 2007; 65(7):1397-1409.

10. Souza EM. Intergenerational interaction in health promotion: a qualitative study in Brazil. Revista de Saúde Pública 2003; 37(4):463-469.

11. Souza EM. Evaluation methods in health promotion programmes: the description of a triangulation in Brazil. Cien Saude Colet 2010; 15(5):2521-2532. Available: http://www.scielosp.org/scielo.php?pid= S1413$81232010000500026 \&$ script $=$ sci_abstract

12. Granville G. A review of intergenerational practice in the UK. Manchester: Beth Johnson Foundation, Metropolitan University; 2002.

13. Thompson B, Kinne S. Social changes theory: applications to community health. In: Bracht N. Health promotion at the community level. London: Sage Publications; 1999. p. 29-46.

14. Ajzen I, Fishbein M. Understanding attitudes and predicting social behaviour. Englewood Cliffs, NJ: Prentice Hall; 1980.

15. Ajzen I. The theory of planned behaviour. Organizational Behaviour and Human Decision Processes 1991; 50:179-211.
16. Bandura A. Social Learning Theory. Englewood Cliffs, NJ: Prentice Hall; 1969.

17. Freire P. Education for critical conscientiousness. New York: Seabury; 1973/1974.

18. Whittemore AR, Buelow J. Health and health promotion in Latin America. In: Bracht N. Health promotion at the community level. London: Sage Publications; 1999.

19. Souza EM. Setting an intergenerational programme in Brazil: process observation as a means of evaluation. Indian Journal of Gerontology 2004; 18(3/ 4):391-409.

20. Butler R. Why survive? Being old in America. New York: Harper \& Row, Publishers; 1975.

21. Companhia de Desenvolvimento do Planalto Central (Codeplan). Pesquisa de informações socioeconômicas das famílias do Distrito Federal (Pisef) DF). Brasília: Codeplan; 2000.

22. Strauss A, Corbin J. Qualitative research: grounded theory procedures and technique. London: Sage Publications; 1990.

23. Glaser B, Straus A. Awareness of dying. Chicago: Aldine Publishing Co.; 1965.

24. Britt MÖ. Meeting the other: a way of fighting age discrimination? A discussion circle with young and old participants in Sweden. Journal of Intergenerational Relationships 2007; 5(2):27-44.

25. Chellam G. Intergenerational affinities: symmetrical life experiences of the young adults and the ageing in Canadian society. Ageing and Human Development 1981; 12(2):79-92.

26. Morrow VM. "Dirty looks" and "trampy places" in young people's accounts of community and neighbourhood: implications for health inequalities. Critical Public Health 2000; 10(2):141-152.

27. Hausdorff JM, Becca LR, Wei JY. The power of ageism on physical function of older persons: reversibility of age related gait changes. Journal of American Geriatrics Society 1999; 47:1346-1349.

28. Silverman D. Doing qualitative research: a practical handbook. London: Sage Publications; 2000.

Artigo apresentado em 05/06/2008

Aprovado em 22/01/2009

Versão final apresentada em 20/02/2009 